Vol 2 No 1 (2018) Page $64-69$

JURNAL OBSESI : JURNAL PENDIDIKAN ANAK USIA DINI

Research \& Learning in Early Childhood Education

https://obsesi.or.id/index.php/obsesi

\title{
Meningkatkan Kedisiplinan Anak Usia Dini Melalui Latihan Pembiasaan Penggunaan Toilet di KB Al-Hidayah Insan Mandiri Kabupaten Bandung
}

\author{
Dikdik Pramono ${ }^{1}$, Anni Risnawati ${ }^{2 凶}$ \\ PG-PAUD, FIP, IKIP Siliwang
}

\begin{abstract}
Abstrak
Tujuan penelitian dalam artikel ini adalah untuk mengetahui kedisiplinan anak usia dini melalui latihan pembiasaan penggunaan toilet dengan baik di KB Al-Hidayah Insan Mandiri Kabupaten Bandung. Latihan kebiasaan menggunakan toilet dengan baik dapat membantu pengetahuan dan pemahaman anak usia dini tentang bagaimana menggunakan toilet dengan baik, menjaga kebersihannya, dan membantu meletakkan aspek-aspek yang terkait dengan penggunaan toilet untuk dapat meningkatkan kedisiplinan anak. Rumusan masalah dalam penelitian ini adalah bagaimana meningkatkan kedisiplinan anak usia dini melalui latihan pembiasaan penggunaan toilet di KB Al-Hidayah Insan Mandiri Kabupaten Bandung. Metode penelitian yang digunakan adalah metode penelitian tindakan kelas. Penelitian tindakan kelas pada penelitian ini terdiri dari dua siklus, masing-masing siklus tiga kali pertemuan yang dilakukan di semester genap (tahun akademik 2017-2018), selanjutnya data dianalisis secara kuantitatif dan kualitatif. Subjek penelitian ini adalah anak usia dini KB Al-Hidayah Insan Mandiri Kabupaten Bandung yang berjumlah 20 orang. Instrumen yang digunakan dalam penelitian ini adalah lembar observasi anak. Hasil penelitian menunjukkan bahwa melalui latihan pembiasaan penggunaan toilet dengan baik dapat meningkatkan kedisplinan anak usia dini di KB Al-Hidayah Insan Mandiri Kabupaten Bandung sebesar $85 \%$.
\end{abstract}

Kata Kunci: kedisiplinan, penggunaan toilet, anak usia dini.

\section{Abstract}

The purpose of this research is to know the discipline of early childhood through the habitual use of toilet training well in KB Al-Hidayah Insan Mandiri Kabupaten Bandung. Good toileting habits can help early childhood knowledge and understanding about how to use the toilet properly, maintain hygiene, and help lay out aspects related to using toilets to improve child self-discipline. The research problem is how to improve the discipline of early childhood through the use of toilet in KB Al-Hidayah Insan Mandiri Kabupaten Bandung. The research method used is classroom action research method. The classroom action research in this study consisted of two cycles, each cycle of three meetings conducted in the even semester (academic year 2017-2018), then the data were analyzed quantitatively and qualitatively. The subjects of this study are early childhood KB Al-Hidayah Insan Mandiri Kabupaten Bandung, amounting to 20 children. The instrument used in this study is a child observation sheet. The results showed that through the use of toilets well can improve the early childhood discipline in KB Al-Hidayah Insan Mandiri Kabupaten Bandung by $85 \%$.

Keywords: discipline, use of toilets, early childhood.

@ Jurnal Obsesi Prodi PG-PAUD FIP UPTT 2018

$\triangle$ Corresponding author : Dikdik Pramono

Address : PG-PAUD, FIP, IKIP Siliwangi

Email : dikdikpramonoaji78@gmail.com

ISSN 2356-1327 (Media Cetak)

Phone : 08231584750

ISSN 2549-8959 (Media Online) 


\section{PENDAHULUAN}

Pendidikan Anak Usia Dini (PAUD) adalah jenjang pendidikan sebelum jenjang pendidikan dasar yang merupakan suatu upaya pembinaan yang ditujukan bagi anak sejak lahir sampai dengan usia enam tahun yang dilakukan melalui pemberian rangsangan pendidikan untuk membantu pertumbuhan dan perkembangan jasmani dan rohani agar anak memiliki kesiapan dalam memasuki pendidikan lebih lanjut, yang diselenggarakan pada jalur formal, nonformal, dan informal. (Indonesia, 2003)

Disiplin akan membantu anak usia dini untuk mengembangkan kontrol dirinya (Suryadi, 2007). Disiplin adalah sebagai proses belajar yang mempengaruhi kepada ketertiban dan mengendalikan diri (Gilbert, 2003). Disiplin juga diartikan sebagai watak yang dimiliki seseorang yang merupakan hasil belajar sekaligus berdasarkan atas faktor yang dibentuk lewat latihan atau disiplin di rumah maupun sekolah (Mashar, 2011). Disiplin adalah pengajaran bimbingan atau dorongan yang dilakukan oleh orang dewasa yang tujuannya menolong anak- anak belajar hidup sebagai makhluk sosial dan untuk mencapai pertumbuhan serta perkembangan mereka (Nizar, 2011). Jadi, kedisiplinan adalah suatu cara untuk membantu anak usia dini agar dapat memgembangkan pengendalian diri dengan mengunakan disiplin anak agar dapat memperoleh suatu batasan untuk memperbaiki tingkah lakunya yang salah dan mendidik anak dalam keteraturan hidup kesehariannya akan memunculkan watak disiplin. Misalnya: Kapan harus membaca Al- Qur'an, hari apa harus membersihkan rumah, jam berapa harus pergi ke sekolah dan mengaji, dan kapan pula harus bermain. Semua itu lama kelamaan akan terbiasa dan terlatih pada diri anak untuk menaati peraturan yang ada. Inilah yang dinamakan disiplin.

Setelah peneliti melakukan observasi awal di KB Al-Hidayah Insan Mandiri Kabupaten Bandung, peneliti menemukan masalah bahwa anak usia dini masih sangat kurang dalam kedisplinan. Hal ini disebabkan guru belum menerapkan kedisiplinanan melalui latihan pembiasaan penggunaan toilet dengan baik. Peneliti mencermati bahwa kenyataan tersebut perlu diatasi dengan membiasakan latihan penggunaan toilet dengan baik pada anak usia dini.

Alasan peneliti tertarik melakukan penelitian tersebut karena peneliti ingin meningkatkan kedisiplinan melalui latihan pembiasaan penggunaan toilet dengan baik pada anak usia dini. Oleh karena itu, peneliti merancang sebuah kegiatan pembelajaran melalui latihan pembiasaan penggunaan toilet dengan baik sesuai dengan indikator anak KB.

Adapun tujuan yang ingin dicapai pada penelitian ini adalah untuk meningkatkan kedisiplin melalui latihan pembiasaan penggunaan toilet dengan baik. Berdasarkan latar belakang masalah yang telah diungkapkan, maka rumusan masalah dalam penelitian ini adalah "Bagaimana meningkatkan kedisiplinan anak usia dini melalui latihan pembiasaan penggunaan toilet di KB Al-Hidayah Insan Mandiri Kabupaten Bandung?".

Manfaat penelitian ini secara khusus untuk melatih anak usia dini dalam latihan pembiasaan melakukan Buang Air Besar (BAB) dan Buang Aie Kecil (BAK) pada tempatnya dengan baik. Manfaat penelitian bagi para guru PAUD dan praktisi pendidikan pada umumnya dapat menerapkan latihan penggunaan toilet dengan baik sejak usia dini yang memperhatikan anak usia dini secara spesifik berdasarkan kemampuan dan kesiapan anak.

Pengertian disiplin menurut Putra (2012), disiplin adalah proses belajar yang mempengaruhi kepada ketertiban dan mengendalikan diri. Jadi, disiplin akan membantu anak untuk mengembangkan kontrol dirinya (Suryadi, 2007). Menurut Affrida (2017), disiplin juga diartikan sebagai watak yang dimiliki seseorang yang merupakan hasil belajar sekaligus berdasarkan atas faktor yang dibentuk lewat latihan atau disiplin di rumah maupun sekolah. Menurut Alim (2016), disiplin adalah pengajaran bimbingan atau dorongan yang dilakukan oleh orang dewasa yang tujuannya menolong anak-anak belajar hidup sebagai makhluk sosial dan untuk mencapai pertumbuhan serta perkembangan mereka yang seoptimalnya. 
Berdasarkan berbagai pendapat yang telah diungkapkan, disiplin dapat disimpulkan sebagai suatu cara untuk membantu anak usia dini agar dapat memgembangkan pengendalian diri. Dengan kedisiplinan, anak dapat memperoleh suatu batasan untuk memperbaiki tingkah lakunya yang salah dan mendidik anak dalam keteraturan hidup keseharian.

Menurut Suryadi (2007), metode yang dapat diterapkan dalam menerapkan kedisiplinan sebagai berikut: a) Penghargaan dalam menegakkan disiplin, sehingga anak usia dini mempunyai motivasi untuk belajar, b) Hukuman secara efektif, yakni, hukuman hanya dapat diberikan apabila anak usia dini berbuat kesalahan dengan sengaja atau melakukan perbuatan buruk.

Menurut Nizar (2009), latihan penggunaan toilet adalah suatu usia untuk melatih anak usia dini agar mampu mengontrol dalam melakukan BAB atau BAK. Menurut Putra (2012), latihan penggunaan toilet merupakan proses pengajaran untuk mengontrol BAB dan atau BAK secara benar dan teratur. Menurut Alim (2006), latihan penggunaan toilet adalah sebuah pembiasaan pelatihan buang air.

Berdasarkan berbagai pengertian yang telah diungkapkan, maka dapat disimpulkan bahwa latihan penggunaan toilet adalah sebuah usaha pembiasaan mengontrol BAB dan atau BAK secara benar dan teratur.

Pengajaran latihan penggunaan toilet pada anak usia dini memerlukan beberapa tahapan, seperti: pembiasaan menggunakan toilet pada anak usia dini untuk buang air sehingga anak cepat beradaptasi, perlu rutinitas apalagi ketika anak terlihat ingin buang air, anak dibiarkan duduk pada waktu-waktu tertentu setiap hari, terutama 20 menit setelah bangun tidur dan selesai makan, ini bertujuan agar anak usia dini dibiasakan dengan jadwal buang airnya. Apabila anak sesekali mengompol dalam masa latihan penggunaan toilet, merupakan hal yang normal. Apabila anak berhasil melakukan penggunaan toilet dengan baik, maka guru atau orang tua dapat memberikan pujian dan jangan menyalahkan apabila anak belum dapat melakukannya dengan baik.

Menurut Sujiono (2005), disiplin adalah salah satu cara yang digunakan untuk membantu anak usia dini dalam mengarahkan sikap dan perilakunya agar dapat diterima secara sosial. Usia 7-12 bulan merupakan tahap awal perkembangan disiplin walaupun masih sederhana yang bentuknya masih berupa pola keteraturan pada kehidupan sehari-hari, seperti latihan pembuangan secara teratur, pola makan, dan pola tidur. Adapun karakterstik kedisiplinan anak usia 2-4 tahun sebagai berikut:

Tabel 1. Karakteristik Kedisiplinan Anak Usia Dini

\begin{tabular}{|c|c|}
\hline \multirow{5}{*}{$\begin{array}{l}\text { Usia } 2 \\
\text { tahun }\end{array}$} & $\begin{array}{lr}\text { Disiplin } & \text { dilakukan } \\
\text { berdasarkan } & \text { pembentukan } \\
\text { kebiasaan dari orang lain. }\end{array}$ \\
\hline & $\begin{array}{l}\text { Cenderung membantah } \\
\text { kehendak orang tua. }\end{array}$ \\
\hline & Sulit diatur \\
\hline & $\begin{array}{l}\text { Dapat mengikuti pola yang } \\
\text { tidak menyulitkan bagi orang } \\
\text { tua pada saat perilaku } \\
\text { menjelajah. }\end{array}$ \\
\hline & $\begin{array}{lrr}\text { Dapat buang air } & \text { pada } \\
\text { tempatnya karena } & \text { telah } \\
\text { menguasai } & \text { otot- } & \text { otot } \\
\text { pelepasan. } & & \\
\end{array}$ \\
\hline \multirow{3}{*}{$\begin{array}{l}\text { Usia } 3-5 \\
\text { tahun }\end{array}$} & $\begin{array}{l}\text { Disiplin melalui cerita fiktif } \\
\text { atau sebenarnya. }\end{array}$ \\
\hline & $\begin{array}{l}\text { Dapat diajak bertukar pikiran } \\
\text { tentang konsekuensi apabila } \\
\text { berbuat salah atau benar. }\end{array}$ \\
\hline & $\begin{array}{l}\text { Disiplin melalu kegiatan } \\
\text { sehari- hari, misalnya: dapat } \\
\text { merapikan kembali mainan } \\
\text { yang habis dipakai, mencuci } \\
\text { tangan sebelum makan, } \\
\text { membuat peraturan tata tertib } \\
\text { di rumah secara menyeluruh. }\end{array}$ \\
\hline
\end{tabular}

\section{METODE}

Penelitian ini dilaksanakan di KB AlHidayah Insan Mandiri Kabupaten Bandung pada semester genap (tahun akademik 20172018). Subjek penelitian adalah anak KB dengan jumlah siswa 20 orang, terdiri dari 16 anak laki-laki dan 4 anak perempuan. Metode penelitian yang dilakukan adalah metode 
penelitian tindakan kelas. Metode ini dilakukan dengan tujuan memperbaiki mutu praktik pembelajaran di kelas. Penelitian Tindakan Kelas (PTK) berfokus pada kelas atau pada proses pembelajaran yang terjadi di kelas, bukan pada input kelas.

PTK harus bertujuan atau mengenai halhal yang terjadi di dalam kelas (Arikunto, 2008). Siklus merupakan ciri khas PTK. Penelitian ini mengacu kepada model siklus yang dikemukakan Arikunto (2006). Proses penelitian ini memiliki empat aspek pokok yang melalui proses dinamis yaitu: perencanaan, pelaksanaan, pengamatan, dan refleksi. Alat pengumpul data dalam penelitian ini adalah lembar observasi sebagaimana berikut:

Tabel 2. Lembar Observasi Aktivitas Anak Usia Dini

\begin{tabular}{|c|l|l|l|l|l|}
\hline No. & \multicolumn{1}{|c|}{$\begin{array}{c}\text { Aspek- } \\
\text { aspek yang } \\
\text { diamati }\end{array}$} & BM & MM & BSH & BSB \\
\hline 1 & $\begin{array}{l}\text { Anak } \\
\text { mampu } \\
\text { menggunaka } \\
\text { n toilet } \\
\text { dibantu dan } \\
\text { diingatkan }\end{array}$ & & & & \\
\hline 2 & $\begin{array}{l}\text { Anak dapat } \\
\text { membuka } \\
\text { celana } \\
\text { sendiri dan } \\
\text { memakai } \\
\text { celana. }\end{array}$ & & & & \\
\hline 3 & $\begin{array}{l}\text { Anak dapat } \\
\text { "cebok" } \\
\text { sesudah } \\
\text { BAB/ BAK. }\end{array}$ & & & & \\
\hline 4 & $\begin{array}{l}\text { Anak } \\
\text { terbiasa } \\
\text { mencuci } \\
\text { tangan } \\
\text { sesudah } \\
\text { selesai } \\
\text { BAB/ BAK. }\end{array}$ & & & & \\
\hline
\end{tabular}

Data hasil pengamatan aktivitas dideskripsikan untuk setiap pertemuan dan dilihat kecenderungannya dalam bentuk persentase dengan menggunakan rumus sebagai berikut:

$$
\mathrm{P}=\frac{F}{N} \times 100 \%
$$

Keterangan:

$\mathrm{P}=$ Persentase

$\mathrm{F}=$ Frekuensi

$\mathrm{N}=$ Jumlah siswa

\section{HASIL DAN PEMBAHASAN}

\section{Hasil Penelitian}

Berdasarkan observasi awal di KB AlHidayah Insan Mandiri Kabupaten Bandung, peneliti melihat bahwa pembiasaan latihan toilet masih rendah sebagaimana hasil pengamatan sebagai berikut:

Tabel 3. Hasil Pengamatan Awal

\begin{tabular}{|c|c|c|c|c|}
\hline No. & $\begin{array}{l}\text { Penil } \\
\text { aian }\end{array}$ & Keterangan & $\begin{array}{c}\text { Juml } \\
\text { ah } \\
\text { Anak }\end{array}$ & $\begin{array}{l}\text { Persenta } \\
\text { se } \\
(\%)\end{array}$ \\
\hline 1 & $\mathrm{BM}$ & Belum Muncul & 13 & 65 \\
\hline 2 & MM & Mulai Muncul & 6 & 30 \\
\hline 3 & $\mathrm{BSH}$ & $\begin{array}{l}\text { Berkembang } \\
\text { Sesuai } \\
\text { Harapan }\end{array}$ & 1 & 5 \\
\hline 4 & BSB & $\begin{array}{l}\text { Berkembang } \\
\text { Sangat Baik }\end{array}$ & - & 0 \\
\hline \multicolumn{3}{|c|}{ Jumlah } & 20 & 100 \\
\hline
\end{tabular}

Dari hasil pengamatan awal, menunjukan bahwa hasil yang mencapai nilai BSB adalah $0 \%$, sedangkan yang mendapat BSH adalah satu orang anak (5\%), sedangkan nilai MM adalah 6 orang anak (30\%), sedangkan nilai BM adalah 13 orang anak $(65 \%)$. Berdasarkan uraian diatas maka dapat penulis simpulkan bahwa hasil pengamatan awal terhadap anak selama kegiatan pembelajaran dengan menggunakan latihan penggunaan toilet training memang sangat perlu dilakukan.

Setelah melakukan pengamatan awal, maka dilakukanlah siklus I dan hasilnya sebagai berikut:

Tabel 4. Hasil Pengamatan Siklus I

\begin{tabular}{|c|c|c|c|c|}
\hline No. & $\begin{array}{c}\text { Penil } \\
\text { aian }\end{array}$ & Keterangan & $\begin{array}{c}\text { Juml } \\
\text { ah } \\
\text { Anak }\end{array}$ & $\begin{array}{l}\text { Persenta } \\
\text { se } \\
(\%) \\
\end{array}$ \\
\hline 1 & $\mathrm{BM}$ & Belum Muncul & 4 & 20 \\
\hline 2 & MM & Mulai Muncul & 11 & 55 \\
\hline 3 & $\mathrm{BSH}$ & $\begin{array}{l}\text { Berkembang } \\
\text { Sesuai } \\
\text { Harapan }\end{array}$ & 5 & 25 \\
\hline 4 & BSB & $\begin{array}{l}\text { Berkembang } \\
\text { Sangat Baik }\end{array}$ & - & 0 \\
\hline \multicolumn{3}{|c|}{ Jumlah } & 20 & 100 \\
\hline
\end{tabular}


Dari hasil pengamatan pada siklus I, menunjukan bahwa hasil yang mencapai nilai BSB adalah $0 \%$, sedangkan yang mendapat nilai BSH adalah 5 orang anak (25\%), sedangkan nilai MM adalah 11 orang anak (55\%), sedangkan nilai BM adalah 4 orang anak (20\%). Berdasarkan uraian diatas, maka dapat peneliti simpulkan bahwa hasil pengamatan terhadap anak usia dini selama kegiatan pembelajaran dengan menggunakan latihan pengguanaan toilet pada siklus I masih kurang karena hasil yang diperoleh belum sesuai dengan yang diharapkan dan perlu masuk pada siklus berikutnya, akan tetapi sudah terjadi peningkatan dari penilaian yang dilakukan sebelumnya.

Dikarenakan hasil siklus I masih belum sesuai dengan yang diharapkan, maka masuk ke siklus II dan hasilnya sebagai berikut:

Tabel 5. Hasil Pengamatan Siklus II

\begin{tabular}{|c|c|c|c|c|}
\hline No. & $\begin{array}{l}\text { Penil } \\
\text { aian }\end{array}$ & Keterangan & $\begin{array}{l}\text { Jml. } \\
\text { Anak }\end{array}$ & $\begin{array}{c}\text { Perse } \\
\text { ntase } \\
(\%)\end{array}$ \\
\hline 1 & $\overline{B M}$ & Belum Muncul & - & 0 \\
\hline 2 & MM & Mulai Muncul & 1 & 5 \\
\hline 3 & BSH & $\begin{array}{l}\text { Berkembang } \\
\text { Sesuai } \\
\text { Harapan }\end{array}$ & 2 & 10 \\
\hline 4 & BSB & $\begin{array}{l}\text { Berkembang } \\
\text { Sangat Baik }\end{array}$ & 17 & 85 \\
\hline \multicolumn{3}{|c|}{ Jumlah } & 20 & 100 \\
\hline
\end{tabular}

Dari pelaksanaan tindakan siklus II dapat diketahui bahwa yang mendapatkan nilai BSB adalah $85 \%$ atau 17 orang anak, sedangkan yang mendapat nilai BSH $10 \%$ atau 2 orang anak, sedangkan mendapat nilai MM 5\% atau 1 orang anak, dan yang mendapat nilai BM $0 \%$ atau tidak ada.

Berdasarkan hasil diatas, maka dapat diambil kesimpulan bahwa penelitian ini sudah berhasil. Hal ini dapat dilihat dari hasil yang diperoleh bahwa hampir semua anak memperoleh nilai BSB dari setiap aspek yang dinilai. Hal ini sudah sesuai harapan, oleh karena itu nilai yang telah ditetapkan telah berhasil, maka penelitian dihentikan pada siklus II.

Dengan melihat perbandingan nilai hasil siklus I dan siklus II, maka terdapat peningkatan yang cukup baik dilihat dari peningkatan disiplin anak usia dini melalui latihan penggunaan pembiasaan toilet training. Dari sejumlah 20 orang anak masih ada 3 orang anak yang belum mencapai nilai $\mathrm{BSB}$, hal ini memang ketiga anak tersebut masih harus dibimbing, namun sekalipun 3 anak ini belum mencapai nilai BSB, namun hal yang paling penting adalah anak tersebut mau berusaha dan mulai melakukan sendiri dalam menggunakan toilet yang baik.

\section{Pembahasan}

Berdasarkan temuan pada pengamatan awal disimpulkan bahwa hasil pengamatan awal terhadap anak selama kegiatan pembelajaran dengan menggunakan latihan penggunaan toilet training memang sangat perlu dilakukan. Hal ini sesuai yang disampaikan Nizar (2009), latihan penggunaan toilet adalah suatu usia untuk melatih anak usia dini agar mampu mengontrol dalam melakukan BAB atau BAK.

Pada siklus 1 didapatkan bahwa hasil pengamatan terhadap anak usia dini selama kegiatan pembelajaran dengan menggunakan latihan penggunaan toilet pada siklus I masih kurang karena hasil yang diperoleh belum sesuai dengan yang diharapkan dan perlu masuk pada siklus berikutnya, akan tetapi sudah terjadi peningkatan dari penilaian yang dilakukan sebelumnya. Hal ini senada dengan yang disampaikan Putra (2012), latihan penggunaan toilet merupakan proses pengajaran untuk mengontrol BAB dan atau BAK secara benar dan teratur dan harus dilakukan secara berulang.

Sedangkan pada siklus 2 didapatkan bahwa hampir semua anak memperoleh nilai BSB dari setiap aspek yang dinilai. Hal ini sudah sesuai harapan, oleh karena itu nilai yang telah ditetapkan telah berhasil, maka penelitian dihentikan pada siklus II. Hal ini sesuai dengan pendapat Alim (2016), disiplin adalah pengajaran bimbingan atau dorongan yang dilakukan oleh orang dewasa yang tujuannya menolong anak-anak belajar hidup sebagai makhluk sosial dan untuk mencapai pertumbuhan serta perkembangan mereka yang seoptimalnya. 


\section{UCAPAN TERIMA KASIH}

Ketua peneliti beserta anggota mengucapkan terimakasih banyak kepada Tim dan KB Al-Hidayah Insan Mandiri Kabupaten Bandung atas kerjasama yang baik selama penelitian ini dilakukan serta Bapak Dr. Ramdhan Witarsa, M.Pd. sebagai pembimbing dalam menulis artikel ini hingga dipublikasikan. Semoga amal baik kita semua diterima Allah SWT.

\section{SIMPULAN}

Berdasarkan penelitian ini, dapat disimpulkan bahwa melalui latihan pembiasaan toilet dapat meningkatkan kedisiplinan anak usia dini KB Al-Hidayah Insan Mandiri Kabupaten Bandung.

Pada observasi awal BM 65\%, MM 30\%, BSH 5\% dan BSB masih 0\%. Pada siklus I yaitu BM 20\%, MM 55\%, BSH 25\%, dan BSB masih $0 \%$. Pada siklus I penelitian belum berhasil maka peneliti melakukan siklus II dengan nilai MM 5\%, BSH 10\%, dan BSB 85\%. Melalui latihan penggunaan toilet dapat meningkatkan kedisiplinan dan kemandirian anak usia dini. Selain meningkatnya disiplin dan kemandirian anak, kemampuan fisik, kemampuan psikologi, dan kemampuan kognitif juga berkembang.

Kemampuan psikologi yaitu kemampuan anak untuk mampu melakukan latihan toilet sebagai anak yang kooperatif. Anak memiliki waktu kering antara 3-4 jam, anak BAK dalam jumlah yang banyak, anak sudah menunjukan keinginan untuk BAB dan BAK. Kemampuan fisik dalam melakukan latihan menggunakan toilet ditunjukkan dengan anak dapat duduk dan jongkok tenang kurang lebih 2-5 menit, anak dapat berjalan dengan baik, anak sudah dapat menurunkan celana dan menaikan celananya sendiri.

Kemampuan kognitif anak nampak apabila anak sudah mampu melakukan latihan menggunakan toilet seperti dapat mengikuti dan menuruti instruksi sederhana, memiliki bahasa sendiri seperti pipis untuk BAK, pup untuk BAB dan anak dapat mengerti reaksi tubuhnya apabila ia ingin BAK atau BAB dan dapat memberitahukan apabila ia ingin buang air.

Berdasarkan dari penelitian yang telah peneliti lakukan, maka peneliti menyarankan hal-hal sebagai berikut: 1. Bagi guru, hendaknya dapat membiasakan anak dalam menggunakan toilet dengan baik setiap akan memulai pembelajaran. 2. Bagi orang tua, diharapkan bisa bekerjasama antara apa yang dilakukan di sekolah dengan di rumah. Bagi masyarakat, agar dapat menciptakan anak-anak yang disiplin untuk di masa yang akan datang.

\section{DAFTAR PUSTAKA}

Affrida, E., N. (2017). Strategi Ibu dengan Peran Ganda dalam Membentuk Kemandirian Anak Usia Pra Sekolah. Journal Obsesi (Journal of Early Chilhood Education, 1(2), 44 - 50. Retrieved from http://journal.stkiptam.ac.id/index.php/ obsesi/article/view/543/290

Alim, M., L. (2016). Upaya Meningkatkan Kemampuan Fisik Motorik Kasar Anak melalui Kegiatan Melambungkan dan Menangkap dengan Berbagai Media Anak Usia Dini di TK Al-Fajar Pekanbaru. Journal Obsesi (Journal of Early Chilhood Education, 2(1), 79 - 89. Retrieved from http://journal.stkiptam.ac.id/index.php/ obsesi/article/view/120/71

Arikunto, S. (2006). Penelitian Tindakan Kelas. Jakarta: PT Bumi Aksara

Arikunto, S. (2008). Prosedur Penelitian Suatu Pendekatan Praktik. Jakarta: Rineka Cipta.

Gilbert, J. (2003). Panduan Melatih Anak Mengatasi Masalah Toilet. London: Erlangga

Indonesia, R. (2003). Undang-Undang Nomor 20 Tahun 2003 Sistem Pendidikan Nasional. Direktorat Pendidikan Menengah Umum. Jakarta.

Mashar, R. (2011). Emosi Anak Usia Dini dan Strategi Pengenbangannya. Jakarta: Kencana.

Nizar, I. (2009). Membentuk dan Meningkatkan Disiplin Anak Usia Dini. Jogjakarta: DIVA Press (Anggota IKAPI).

Putra, N. (2012). Penelitian Kualitatif : Pendidikan Anak Usia Dini. Jakarta: Rajawali Pers.

Syahrena, E. (2011). Mengembangkan Perilaku Sehat pada Anak Usia 2-4 Tahun. Jalarta: Derektur Pembinaan PAUD.

Suryadi. (2007). Cara Efektif Memahami Perilaku Anak Usia Dini. Jakarta: EDSA Mahkota.

Sujiono, B. (2005). Menu Pembelajaran Anak Usia Dini. Jakarta: Yayasan citra Pendidikan Indonesia. 